\title{
SILVER MINERALS AND PARAGENESIS IN THE KANGJIAWAN Pb-Zn-Ag-Au DEPOSIT OF THE SHUIKOUSHAN MINERAL DISTRICT, HUNAN PROVINCE, CHINA
}

\author{
NANSHI ZENG AND EIJI IZAWA \\ Department of Earth Resources Engineering, Kyushu University, Fukuoka, 812-8581, Japan \\ YOSHINOBU MOTOMURA \\ Department of Earth and Planetary Sciences, Kyushu University, Fukuoka, 812-8581, Japan \\ LAIREN LAI \\ Research Institute of Geology for Mineral Resources, Guilin, 541004, People's Republic of China
}

\begin{abstract}
The Kangjiawan deposit, in the Shuikoushan district, Hunan Province, China, is a representative hydrothermal $\mathrm{Pb}-\mathrm{Zn}-\mathrm{Ag}-$ $\mathrm{Au}$ deposit in this region. The orebodies consist mainly of pyritic $\mathrm{Pb}-\mathrm{Zn}$ ores. Silver minerals are associated with $\mathrm{Pb}-\mathrm{Zn}$ mineralization. Ag-bearing $\mathrm{Pb}-\mathrm{Zn}$ ores in the deposit are characterized by $\mathrm{Ag}>\mathrm{Cu}>\mathrm{Sb}$ content. Silver occurs mainly as silver minerals, such as minor argentian tetrahedrite, freibergite and abundant polybasite-arsenpolybasite, pearceite and pyrargyriteproustite, and all are hosted in galena. The assemblages of silver minerals found in the major orebodies change from the southern to the northern part, from argentian tetrahedrite + freibergite + pearceite + arsenpolybasite + pyrargyrite-proustite in the south to polybasite-arsenpolybasite + pyrargyrite, and to pyrargyrite in the north.
\end{abstract}

Keywords: silver minerals, tetrahedrite, freibergite, polybasite-arsenpolybasite, pearceite, pyrargyrite-proustite, Kangjiawan $\mathrm{Pb}-$ $\mathrm{Zn}-\mathrm{Ag}-\mathrm{Au}$ deposit, Hunan Province, China.

\section{SOMMAIRE}

Le gisement de Kangjiawan, situé dans le district de Shuikoushan, province de Hunan, en Chine, est représentatif des gisements hydrothermaux à $\mathrm{Pb}-\mathrm{Zn}-\mathrm{Ag}-\mathrm{Au}$ de cette région. Les gisements contiennent surtout un minerai pyritique à $\mathrm{Pb}-\mathrm{Zn}$. Des minéraux d'argent sont associés à la minéralisation $\mathrm{Pb}-\mathrm{Zn}$. Dans le minerai $\mathrm{Pb}-\mathrm{Zn}$ contenant de l'argent, la teneur du minerai répond à la relation $\mathrm{Ag}>\mathrm{Cu}>\mathrm{Sb}$. L'argent se trouve surtout dans les minéraux d'argent, par exemple tétraédrite argentifère et freibergite accessoires, et polybasite-arsenpolybasite, pearceïte et pyrargyrite-proustite plus abondantes, et tous englobées dans la galène. Les assemblages de minéraux d'argent des gisements importants varient du sud vers le nord, de tétraédrite argentifère + freibergite + pearceïte + arsenpolybasite + pyrargyrite-proustite dans le sud à polybasite-arsenpolybasite + pyrargyrite, et à pyrargyrite dans le nord.

(Traduit par la Rédaction)

Mots-clés: minéraux d'argent, tétraédrite, freibergite, polybasite-arsenpolybasite, pearceïte, pyrargyrite-proustite, gisement à $\mathrm{Pb}-\mathrm{Zn}-\mathrm{Ag}-\mathrm{Au}$ de Kangjiawan, province de Hunan, China.

\section{INTRODUCTION}

Silver minerals of the Ag-Sb(As)-S system, including pyrargyrite and polybasite, are very important constituents of the Kangjiawan $\mathrm{Pb}-\mathrm{Zn}-\mathrm{Ag}-\mathrm{Au}$ deposit, Hunan Province, China. This deposit, which contains relatively low levels of copper and antimony, thus pro- vides a good opportunity to study the $\mathrm{Ag}-\mathrm{Sb}(\mathrm{As})-\mathrm{S}$ system because ores consist of a simple assemblage of metallic minerals. A research project on silver occurrences in polymetallic deposits of China was organized by the Chinese National Nonferrous Metal Industry Corporation (CNNMIC) over the interval 1983 to 1992; in this context, the mineralogy, parageneses of ore min-

§ E-mail address: zeng@ mine.kyushu-u.ac.jp 
erals and coexisting silver sulfosalts in the Kangjiawan deposit have been investigated in detail.

The major characteristics of mineralization in the Kangjiawan deposit, representative of hydrothermal $\mathrm{Pb}-$ Zn deposits in China, have been described by Yang (1985) and Liu (1986, 1996). In this paper, we briefly describe the characteristics of mineralization of the deposit, and focus our attention on the occurrence and paragenetic relations of the silver minerals.

\section{Geological Setting and Ore Deposit}

The Shuikoushan mineral district, including the Shuikoushan skarn-type $\mathrm{Cu}-\mathrm{Pb}-\mathrm{Zn}$ deposit and the Kangjiawan hydrothermal $\mathrm{Pb}-\mathrm{Zn}-\mathrm{Ag}-\mathrm{Au}$ deposit, is located in the central part of Hunan Province (Fig.1). Basement rocks in the district consist of Devonian limestone and Carboniferous dolomite. Rocks exposed near the deposits are predominantly argillaceous limestone of Lower Permian age, clastic rocks of Middle to Upper Permian age and limestone of Lower Triassic age, and all these are unconformably overlain by clastic formations of Jurassic and Cretaceous age (Yang 1985, Song 1989). These sedimentary units of Lower and Middle Permian age have been folded and locally overturned. A series of N-S-trending folds and reverse faults form the structural framework of the region. The Shuikoushan granodiorite lopolith (K-Ar age in the range 143-150 Ma: Yang 1985) has intruded Carboniferous and Permian carbonate rocks, and formed a contact-metamorphic zone consisting mainly of andradite and diopside.
The contact zone is tens of meters in thickness, more than a thousand meters in lateral and vertical, and the Shuikoushan skarn-type $\mathrm{Pb}-\mathrm{Zn}-\mathrm{Cu}$ deposit occurs in the contact zone (Song 1989).

The Kangjiawan $\mathrm{Pb}-\mathrm{Zn}-\mathrm{Ag}-\mathrm{Au}$ deposit is far from the igneous contact zone, about $1.8 \mathrm{~km}$ northeast from the Shuikoushan granodiorite body. Although another body of diorite porphyry (129 Ma: Yang 1985) is exposed on the eastern side less than $900 \mathrm{~m}$ from the Kangjiawan deposit, sulfur isotopic studies show that pulse of magmatic activity had no link with mineralization (Song 1989). The Kangjiawan deposit is a blind deposit and occurs at a depth of $160 \mathrm{~m}$ from the surface in the northern part and $590 \mathrm{~m}$ in the southern part (Yang 1985). The deposit consists of seven large and 25 small ore lenses distributed over a N-S-trending area of about $2500 \times 800 \mathrm{~m}$ (Fig. 1). Among the major orebodies (IVII, Fig. 2A), five orebodies (I-V) occur in the silicified breccia zone, which is in or near the unconformity between Jurassic and Permian rocks and caused by the movement of Fault $22\left(\mathrm{~F}_{22}\right)$, one of the major faults in the area. Two orebodies (VI and VII) occur in the Lower Permian argillaceous limestone of the hanging wall of $\mathrm{F}_{22}$ (Fig. 3). The orebodies are stratiform or lenticular, strike N-S, mainly dip to the west, and locally dip to the east with an angle of 15 to $40^{\circ}$. The largest one (orebody I) has a size of about $1490 \times 520 \times 9 \mathrm{~m}$ (Zhang 1990). The orebodies consist of massive pyritic ore with significant amounts of sphalerite, galena, and minor arsenopyrite, silver sulfosalts and electrum, associated with quartz and calcite. The grade of the ore

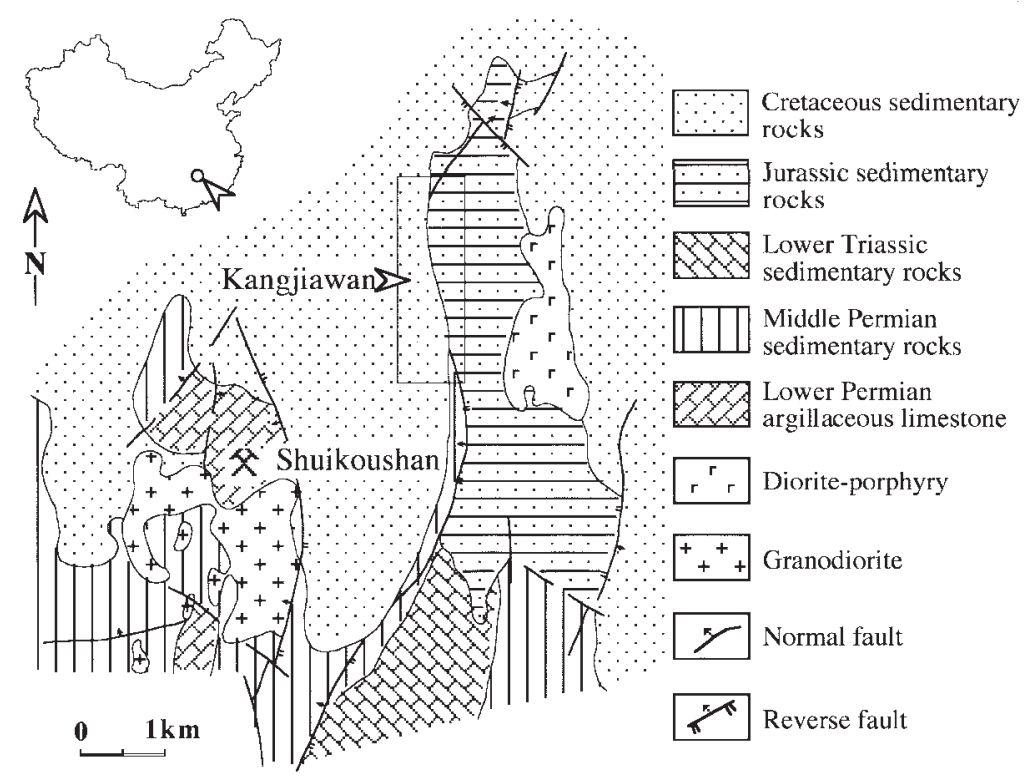

FIG. 1. Geological map of the Shuikoushan mineral district, China (after Yan 1985). 
averages 3.9 wt. $\% \mathrm{~Pb}, 4.5$ wt. $\% \mathrm{Zn}, 86.8 \mathrm{~g} / \mathrm{t} \mathrm{Ag}$, and $2.68 \mathrm{~g} / \mathrm{t} \mathrm{Au}$ (Liu 1986), but the copper content is very low, $320 \mathrm{ppm}$ on average (Li 1991).

Some skarn and hornfels are found in the south of the Kangjiawan deposit (Yang 1985). Silicification, the major type of alteration, occurs mainly in the breccia zone. White mica alteration ("sericitization"), carbonatization and chloritization are limited to areas in or near the orebodies. Otherwise, hydrothermal alteration is not extensive in the area.

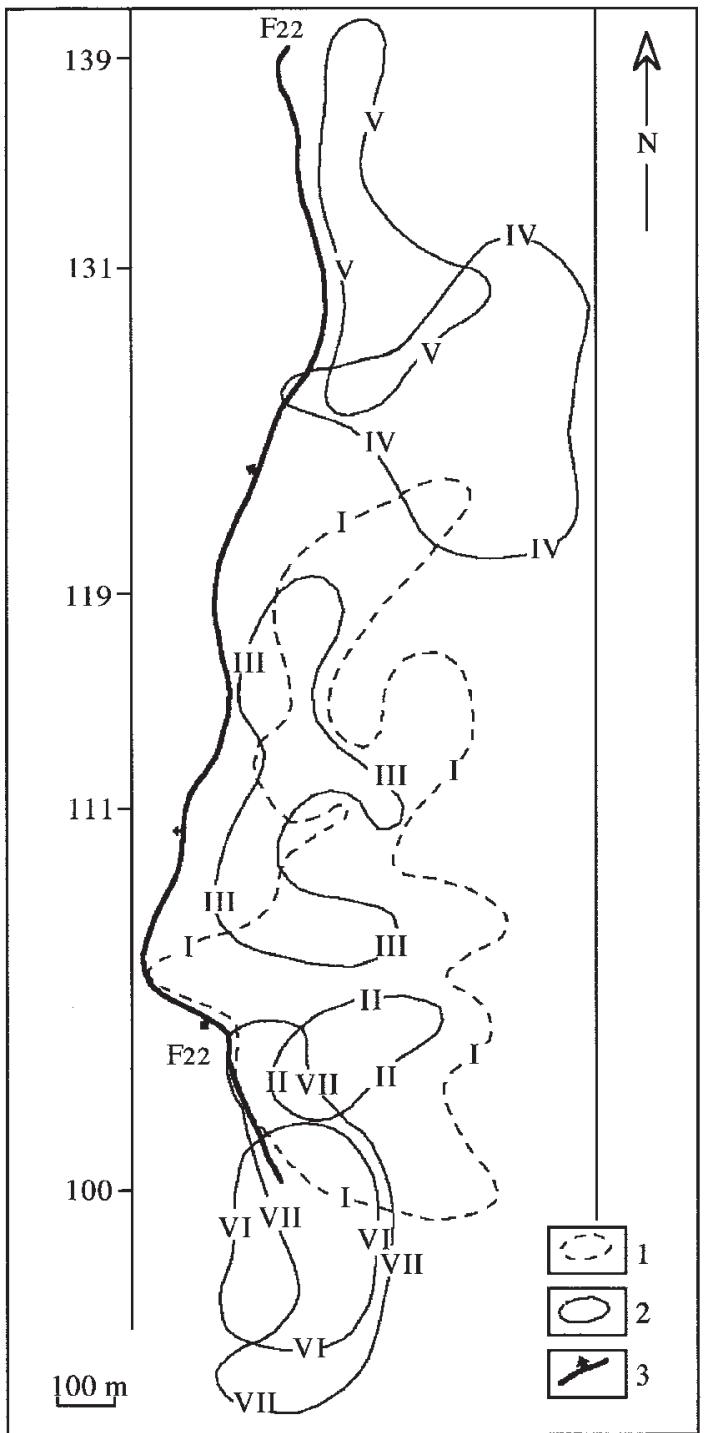

1: Boundary of ore body I

2: Boundary of II-VII ore bodies

3: Fault

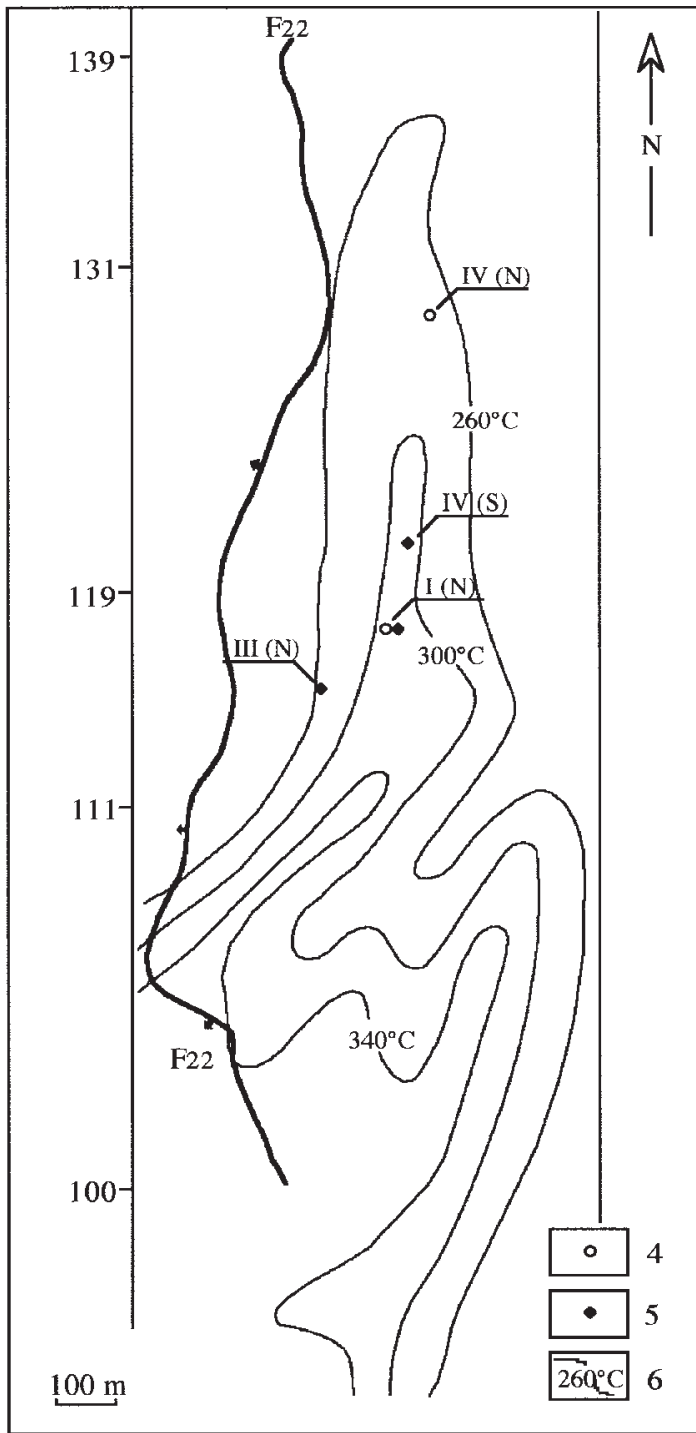

4: Fluid inclusion sample

5: Arsenopyrite sample

6: Decrpitation isothermal of pyrite

$\mathrm{N}=$ northern part \& $\mathrm{S}=$ southern part

FIG. 2. General plans of the Kangjiawan deposit. Exploration lines (E-W) are denoted by numbers 100 to 139. Left: Distribution and shape of major ore bodies I-VII (after Zhang 1991). Right: Locations of samples for fluid inclusion and arsenopyrite geothermometry. Contours of decrepitation temperatures for pyrite are shown (modified from Yan 1985 and Zhang 1991). 

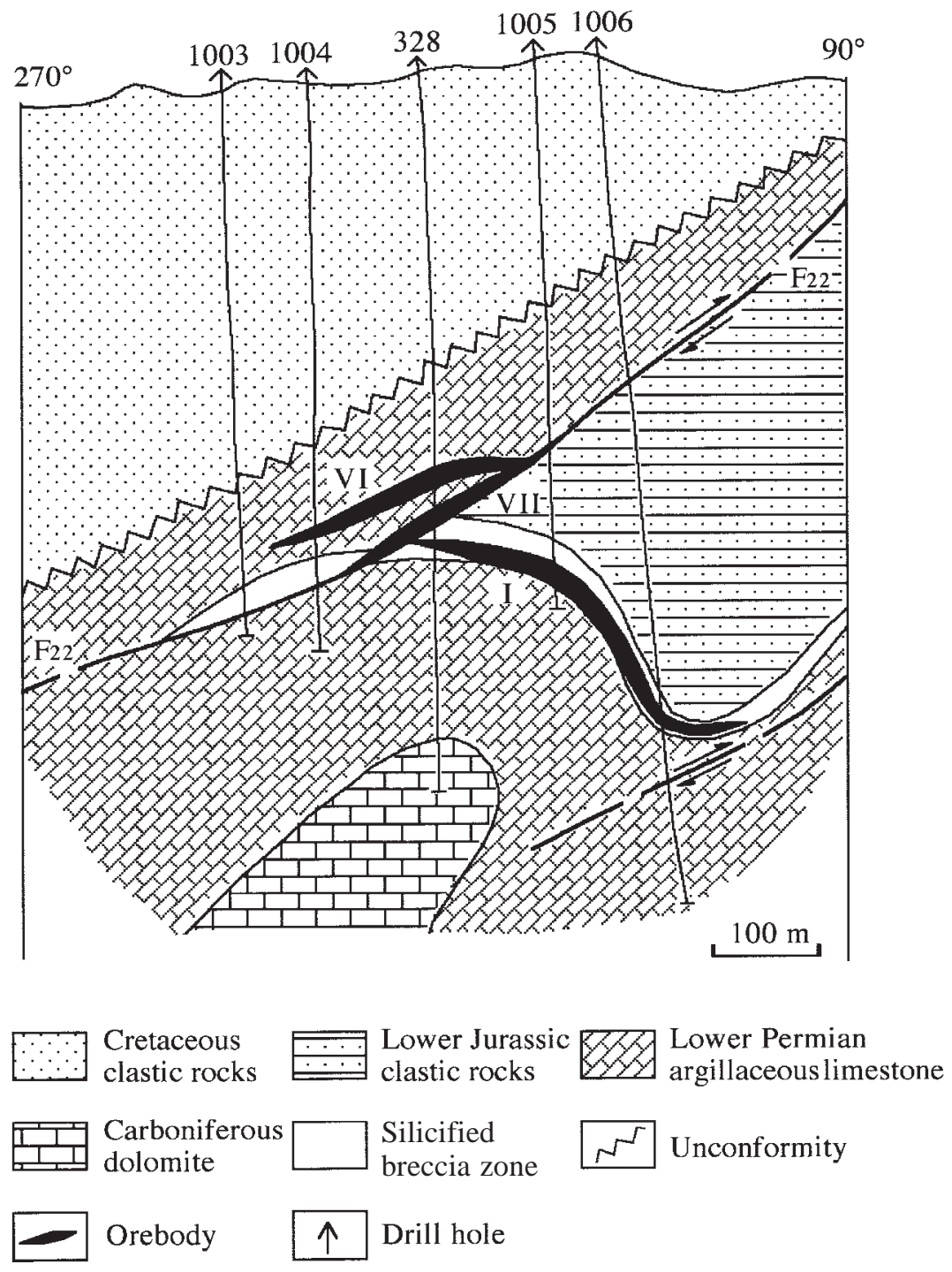

FIG. 3. East-west cross-section along 100 line (after Yan 1985).

\section{Samples and Analytical Methods}

In this study, 385 specimens of ore were collected from orebodies I, III, IVand VI on the $-198 \mathrm{~m}$ and -230 $\mathrm{m}$ levels (Fig. 4). In addition, two samples of ore $(20 \mathrm{~kg}$ each), for the study of mineralogical balance, were collected from orebodies IV and VI ( $-230 \mathrm{~m}$ level). About 100 polished sections and thin sections were examined optically, and some polished sections of galena were observed after chemical etching with dilute nitric acid. Electron-microprobe analyses were carried out with a Shimazu 810-Q electron-probe microanalyzer (EPMA) at the laboratory of Research Institute of Geology for Mineral Resources, CNNC, and a JCXA-733 electronprobe microanalyzer at Kyushu University, Japan. The analyses were done at $20 \mathrm{kV}, 0.01 \mu \mathrm{A}$ beam current and $20 \mathrm{~s}$ counting time, using $\mathrm{PbS}, \mathrm{Ag}, \mathrm{CuFeS}_{2}, \mathrm{ZnS}, \mathrm{MnS}$, $\mathrm{Sb}_{2} \mathrm{Te}_{3}$, CoAsS and $\mathrm{Bi}_{2} \mathrm{Se}_{3}$ as standards, with ZAF correction. Wavelengths employed were $\mathrm{Pb} M \alpha, \operatorname{Ag} L \alpha$, $\mathrm{Cu} K \alpha, \mathrm{Fe} K \alpha, \mathrm{Zn} K \alpha, \mathrm{Mn} K \alpha, \mathrm{Sb} L \alpha, \mathrm{As} L \alpha, \mathrm{Bi} L \alpha, \mathrm{S} K \alpha$ and $\operatorname{Se} L \alpha$. X-ray diffration data were obtained by using a Rigaku type-2001 X-ray diffractometer (XRD) with a $\mathrm{Cu}$ target and quartz as an internal standard. The 220 and 440 reflections were used for calculation of the unit- 


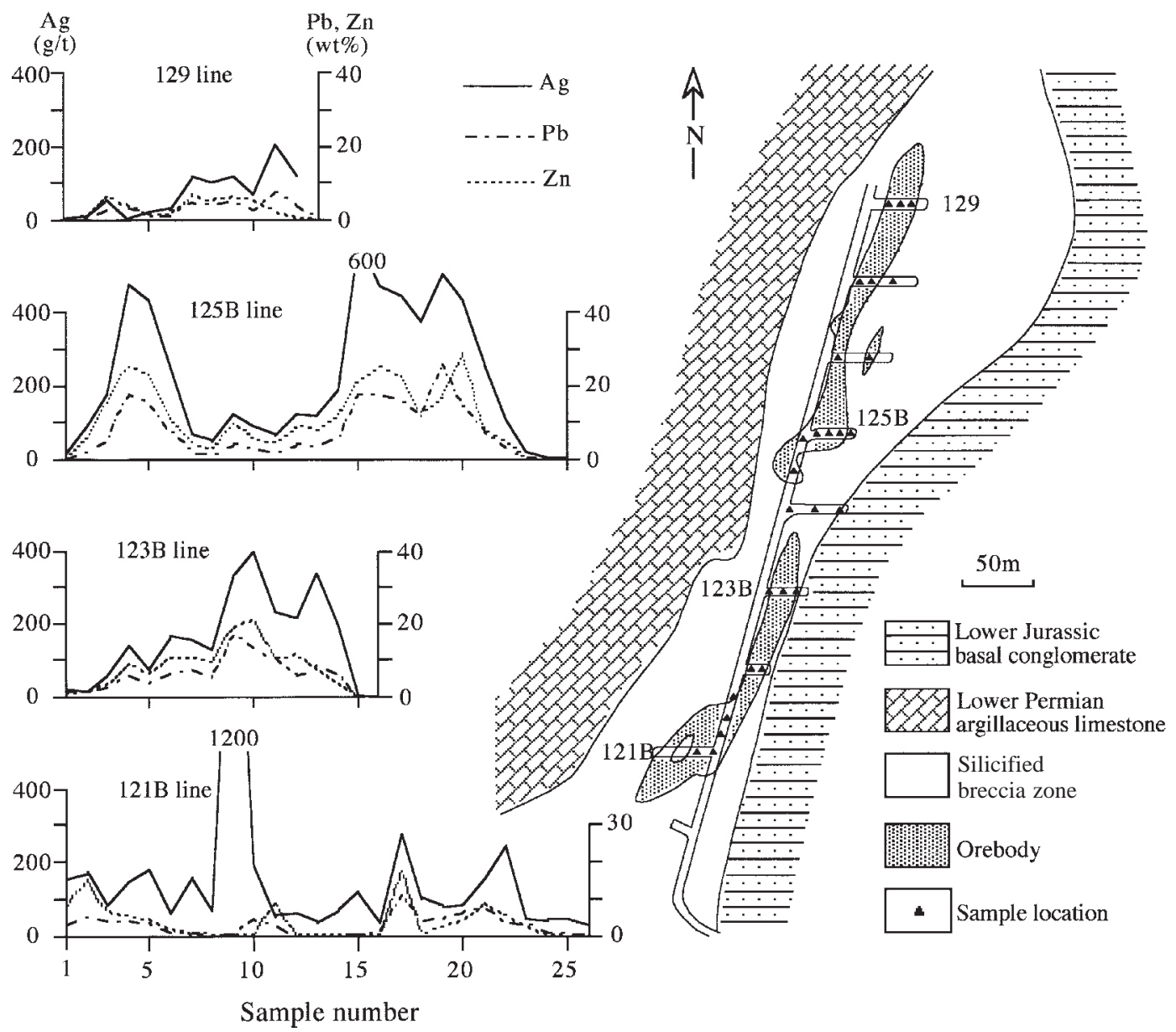

FIG. 4. Plan of orebody IV ( $-230 \mathrm{~m}$ level) with the variations of $\mathrm{Ag}, \mathrm{Pb}$ and $\mathrm{Zn}$ grades in some tunnels.

cell edge of galena. Specimens intended for chemical analysis were obtained by channel sampling, and measurements of major metallic elements were carried out in the laboratory of the Shuikoushan mine by a wetchemical analysis method for $\mathrm{Pb}$ and $\mathrm{Zn}$, and atomic absorption method for Au and Ag. Some samples were re-measured by atomic absorption method in the chemical laboratory of the Research Institute of Geology for Mineral Resources, CNNC, and the results from both laboratories are in agreement. The levels of some trace elements like $\mathrm{Cu}, \mathrm{Sb}, \mathrm{As}$ and $\mathrm{Bi}$ were investigated with bulk samples at Kyushu University with a Rigaku RIX 3100 X-ray-fluorescence (XRF) spectrometer. Temperatures of freezing and homogenization of fluid inclusions in quartz were obtained with a Linkam-600PM heating-cooling stage, with a rate of $4^{\circ} \mathrm{C} / \mathrm{min}$. for heating measurements and $0.5^{\circ} \mathrm{C} / \mathrm{min}$. for cooling measurements.

\section{Ore Mineralogy}

Ores in the Kangjiawan deposit consist of three major types: pyritic, pyrite- $\mathrm{Pb}-\mathrm{Zn}$ and $\mathrm{Pb}-\mathrm{Zn}$ ores (Figs. $5 \mathrm{~A}, \mathrm{~B})$. Ore minerals are mainly pyrite, sphalerite, galena, small amount of arsenopyrite, and trace amounts of chalcopyrite, pyrrhotite, bournonite, silver sulfosalts and electrum. Gangue minerals are quartz, calcite, and small amounts of white mica and chlorite. Trace amount of fine-grained euhedral K-feldspar of the adularia habit was found associated with quartz locally.

Pyrite is the most abundant sulfide mineral, and it can be divided into two generations on the basis of mineralogical features and occurrences. The earlier generation consists of euhedral to subhedral pyrite having a grain size mainly between 0.02 to $0.5 \mathrm{~mm}$, and generally showing zoning (Figs. 5A, C, D). EPMA analyses show that the pyrite is chemically pure in the core, and 


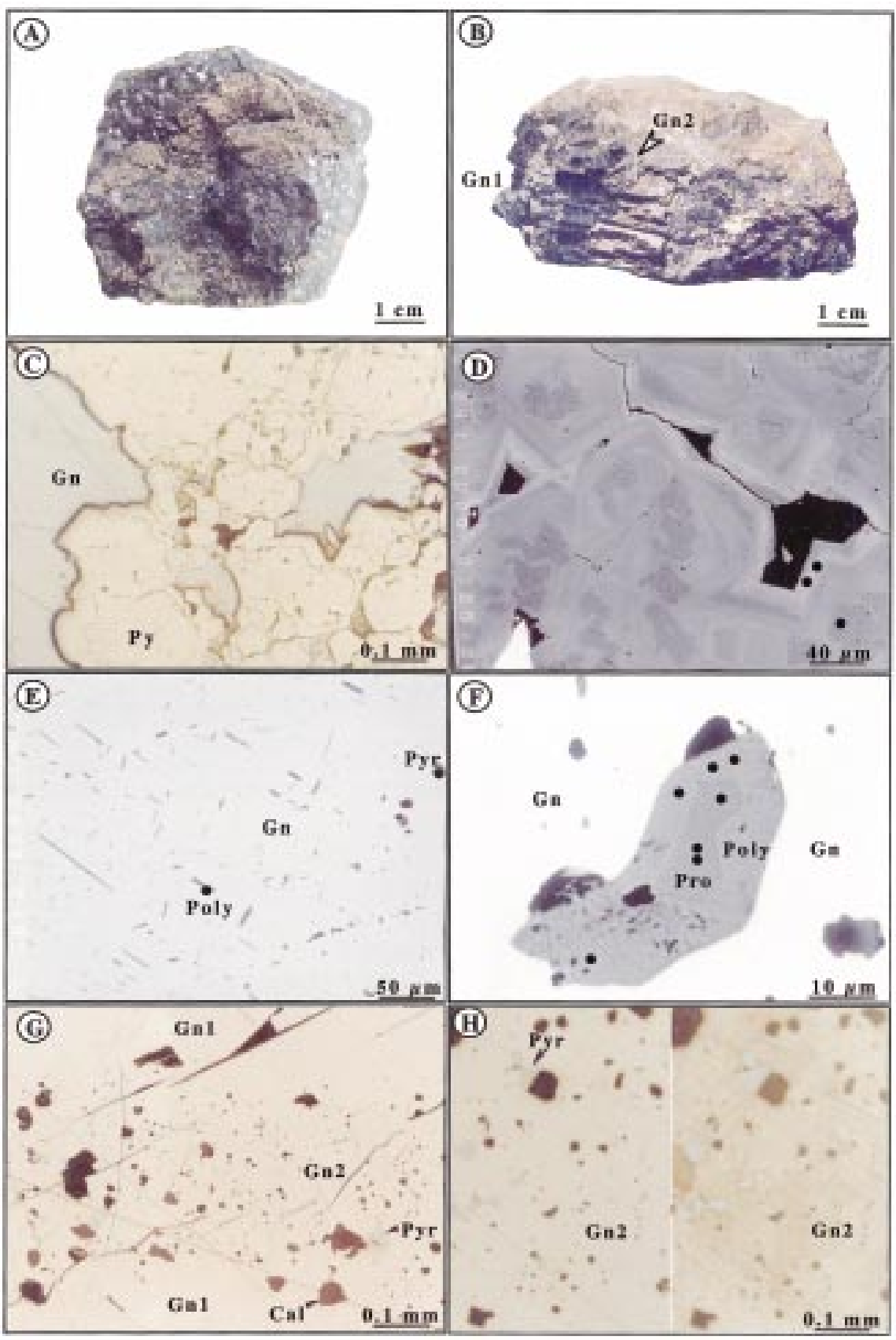

FIG. 5. Photographs of ores and silver minerals. A. Massive pyrite- $\mathrm{Pb}-\mathrm{Zn}$ ore. B. Massive Pb-rich ore with two generations of galena. The later fine-grained galena (Gn2) fills in the fractures of coarse-grained galena (Gn1) ore. C. Photomicrograph of zoned pyrite (Py). D. Back-scattered electron image of zoned pyrite with the high-As rim. Black dots are points of EPMA analyses. E. Back-scattered electron image showing exsolusion-like inclusions of polybasite (Poly) and pyrargyrite (Pyr) occurring along $\{100\}$ of the early coarse-grained galena. F. Back-scattered electron image of silver minerals in the early galena. Proustite (Pro) is surrounded by arsenpolybasite (Poly). G. Photomicrograph showing the early coarse-grained galena (Gn1) is cross-cut by the later galena (Gn2) with abundant pyrargyrite (Pyr) and calcite (Cal). H. Photomicrographs of pyrargyrite in the later fine-grained galena veinlets. Photomicrograph (right) showing grain boundary of galena (etched with diluted $\mathrm{HNO}_{3}$ ). 
has higher arsenic (maximum $4.75 \mathrm{wt} . \% \mathrm{As}$ ) at the rim. Approximately $95 \%$ of the pyrite can be classified as belonging to the earlier generation. The later generation consists of euhedral to anhedral pyrite having a size of $0.01-0.2 \mathrm{~mm}$, and associated with sphalerite and galena that fill fractures in the pyrite orebodies. It is chemically homogeneous.

Sphalerite in general has a high FeS content, which shows zoning from 8 mole $\%$ in the core to 2 mole $\%$ in rim. The FeS content also decreases from the southern part to the northern part in each major orebody. In the southern part of an orebody, some zoned grains of sphalerite include fine-grained blebs of chalcopyrite at the rim. The sphalerite commonly contains about 0.3 wt. $\% \mathrm{Cd}$, and the $\mathrm{Cd}$ content in some grains increases to about 0.8 wt. $\%$, but does not show a clear zonation. A small amounts of reddish sphalerite, which may show a rhombic dodecahedron morphology, is distributed mainly in the northern part of the deposit (north of 111 exploration line in Fig. 2A: Li \& Liu 1984). It is very low in Fe content $(<0.2$ mole $\% \mathrm{FeS})$ and without any $\mathrm{Cd}$. The reddish sphalerite commonly cuts or replaces the earlier iron-rich sphalerite.

Galena also is present in two generations. The earlier generation forms the major part of $\mathrm{Pb}-\mathrm{Zn}$ orebodies. The galena is characterized by its larger grain-size $(>0.5$ $\mathrm{mm}$ ), and the presence of fine-grained tetrahedrite relics, or polybasite and pyrargyrite inclusions. The galena commonly forms massive aggregates. The later generation was observed in orebody I. It is fine grained $(<0.1$ $\mathrm{mm}$ ), and occurs as veinlets that cut the earlier galena. The later galena is intergrown with abundant coarsegrained pyrargyrite and calcite, and no inclusions of a silver mineral were found in it (Figs. 5E, G, and H). XRD data show that the unit-cell edge of the early galena is $5.933 \pm 0.003 \AA$, suggesting low levels of minor-element concentrations. EPMA analyses also indicate that the early galena contains only several hundreds ppm to undetectable silver, less than $500 \mathrm{ppm}$ to undetectable antimony, and undetectable bismuth. The silver, antimony and bismuth all are undetectable in the later galena.

Arsenopyrite is minor but widespread. Commonly, it is easily observed in the southern part and is rare in the northern part of the major orebodies, especially orebody IV. It shows a close relationship with $\mathrm{Pb}-\mathrm{Zn}$ mineralization, and is mainly distributed in quartz and pyrite, or sporadically in galena. The arsenopyrite is euhedral to subhedral, and its grain size is mostly in a range of $0.2-0.5 \mathrm{~mm}$. The coarsest grains can be $>1 \mathrm{~mm}$, and the finest ones are $<0.01 \mathrm{~mm}$ (Yang \& Lin 1987). The arsenic content of the arsenopyrite ranges from 29 to 31 at. \% in the deposit, as described later.

Chalcopyrite is a minor mineral in the deposit. It occurs mostly as blebs in sphalerite, or as independent fine grains in quartz. It is observed normally in the southern part and is absent in the northern part of each major orebody.
Trace amounts of bournonite were found in the galena. Like chalcopyrite, it commonly occurs in the southern part of a given orebody. It is fine grained and irregular in form, and intimately associated with argentian tetrahedrite. The bournonite seems to be formed during the replacement of argentian tetrahedrite by galena.

\section{Silver Distribution and Silver Minerals}

Silver minerals show an intimate association with the $\mathrm{Pb}-\mathrm{Zn}$ mineralization (Fig. 4). They occur mainly in $\mathrm{Pb}-\mathrm{Zn}$ ore or the pyrite- $\mathrm{Pb}-\mathrm{Zn}$ ore. The silver grade ranges from 2 to $1180 \mathrm{~g} / \mathrm{t}$, averaging $86.8 \mathrm{~g} / \mathrm{t}$ (Liu 1986). The silver grade increases from the southern part to the northern part in the deposit (Li \& Liu 1984), and in each major orebody. The results of chemical analyses for 285 samples show that amount of Ag is positively correlated with $\mathrm{Pb}(r=0.85)$ and $\mathrm{Zn}(r=0.5)$. A mineralogical balance based on a modal analysis of polished sections suggests that about $90 \%$ of the silver is concentrated in galena, mainly as included silver minerals. These silver minerals are electrum, argentian tetrahedrite, freibergite, pearceite, polybasite-arsenpolybasite and pyrargyriteproustite. Although Li \& Liu (1984) reported that stromeyerite is one of major silver mineral, we did not find it. Native silver and hessite were reported as trace amounts of minerals associated with electrum in pyrite, and a minor amount of acanthite also was reported to occur in galena (Yang 1985, Li 1991).

Electrum occurs in microfractures or interstices of pyrite, sphalerite and quartz. Most of the grains are about 0.2 to $1 \mu \mathrm{m}$, and the largest domain is about 53 $\mu \mathrm{m}$ across (Lin \& Yang 1986). Commonly, the electrum contains between 35 and 65 wt.\% Ag (Liu 1990).

Argentian tetrahedrite - freibergite is a solid-solution series, which can be written $(\mathrm{Cu}, \mathrm{Ag})_{10}\left(\mathrm{Fe}, \mathrm{Zn}_{2} \mathrm{Sb}_{4} \mathrm{~S}_{13}\right.$ (e.g., Ebel \& Sack 1991, Sack 1992). Riley (1974) first restricted the terms of argentian tetrahedrite and freibergite to tetrahedrite-like phases containing less or greater than $20 \mathrm{wt} \% \mathrm{Ag}$, respectively. On the basis of observations of the occurrences of argentian tetrahedrite and freibergite in Ag-bearing polymetallic deposits of southern China, we found that the argentian tetrahedrite, which is associated with sphalerite and chalcopyrite, occurs as a major Ag-bearing mineral in many Ag-bearing deposits. The grain size of the argentian tetrahedrite is rather larger than that of freibergite. It mostly ranges from tens of $\mu \mathrm{m}$ to several $\mathrm{mm}$. In contrast to argentian tetrahedrite, the freibergite, associated with some Agrich minerals like pyrargyrite, polybasite or miargyrite, occurs only as a trace Ag-bearing mineral in Ag-rich part of the Ag-bearing deposits in southern China (Zeng 1989). Freibergite is commonly less than $10 \mu \mathrm{m}$ in size. Because of the difference in their mode of occurences, we agree with Riley (1974) in dividing the solid-solution series into two different terms, argentian tetrahedrite and freibergite, and using four $\mathrm{Ag}$ atoms in the total 
$12 \mathrm{Cu}$ sites (about 23-24 wt.\% Ag) as the dividing point of the solid-solution series. The chemical formula of argentian tetrahedrite can be written as: $\mathrm{Ag}_{x} \mathrm{Cu}_{y}$ $(\mathrm{Fe}, \mathrm{Zn})_{2} \mathrm{Sb}_{4} \mathrm{~S}_{13}(x+y=10 ; x \leq 4, y \geq 6)$.

Argentian tetrahedrite is a minor silver mineral in the Kangjiawan deposit. It seems to have formed early, as it was replaced by galena, and occurs as a small relic in earlier coarse-grained galena observed in the southern part of each major orebody. Sparse blebs of chalcopyrite can also be observed occasionally in sphalerite. In contrast to the southern part, argentian tetrahedrite and chalcopyrite were not found in the northern part. Argentian tetrahedrite in the deposit contains 15 to 18 wt. $\% \mathrm{Ag}$, and is zinc-rich ( $>5 \mathrm{wt} . \%)$ with a very low level of iron $(<1 \mathrm{wt} . \%)$, and the ratio As/Sb is about 0.02 to 0.06 (Table 1 ).

Fine-grained freibergite was found in samples from the southern part of orebody IV. The grains are less than $10 \mu \mathrm{m}$ in diameter, and occur in interstices of galena grains. They contain about 25 to $26 \mathrm{wt} . \% \mathrm{Ag}$. Compared to argentian tetrahedrite, the freibergite contains higher iron (1.48 wt.\%) and lower zinc (<4.50 wt.\%; Table 1).

Pearceite and polybasite-arsenpolybasite are common in the deposit. The pearceite is found in the earlier coarse-grained galena of the southern part to the central part, and the polybasite-arsenpolybasite is mainly found in the central part and northern part of each major orebody. They occur as fine-grained blebs or lenticular inclusions, commonly as exsolution-like intergrowths along the direction of $\{100\}$ of the galena (Fig. 5E). Some grains of arsenpolybasite are found around $\mathrm{Sb}$ bearing proustite (Fig. 5F). The arsenic content in the polybasite-arsenpolybasite series decreases from the central part to the northern part (Table 1).

A member of the pyrargyrite-proustite solid-solution series is one of the most abundant silver minerals in the deposit. It occurs as blebs in the coarse-grained galena,

TABLE 1. RESULTS OF EPMA ANALYSES OF SOME SLVER MINERALS FROM THE KANGJLAWAN DEPOSIT, CHINA

\begin{tabular}{|c|c|c|c|c|c|c|c|c|c|}
\hline \multirow{2}{*}{$\begin{array}{c}\text { Sample no. } \\
\text { (locality) }\end{array}$} & \multirow{2}{*}{$\begin{array}{c}\text { Mineral } \\
\text { name }\end{array}$} & \multicolumn{8}{|c|}{ composition (wt \%) } \\
\hline & & $\mathrm{Ag}$ & $\mathrm{Cu}$ & $\mathrm{Fe}$ & $\mathrm{Zn}$ & $\mathrm{Sb}$ & As & $\mathbf{S}$ & total \\
\hline K4-16 (IV-S) & tetrahedrite & 17.62 & 24.79 & 0.88 & 5.19 & 26,91 & 0.70 & 23.04 & 99.13 \\
\hline K4-16 (IV-S) & tetrahedrite & 18.07 & 23.96 & 1.10 & 4.88 & 26.90 & 0.75 & 23.25 & 98.90 \\
\hline K4-18 (IV-S) & tetrahedrite & 15.67 & 26.18 & 0.77 & 5.73 & 26.79 & 1.83 & 22.21 & 99.18 \\
\hline $\mathrm{K} 4-18$ (IV-S) & freibergite & 25.14 & 18.45 & 1.48 & 4.36 & 26.29 & 1.05 & 21.90 & 98.67 \\
\hline K4-18 (IV-S) & proustite & 64.30 & 0.37 & 0.02 & 0.08 & 4.51 & 11.00 & 18.40 & 98.68 \\
\hline K4-18 (IV-S) & proustite & 63.40 & 0.48 & - & - & 5.22 & 10.49 & 18.68 & 98.27 \\
\hline K4-18 (IV-S) & pyrargyrite & 60.61 & 0.02 & - & - & 17.06 & 3.61 & 18.40 & 99.70 \\
\hline $\mathrm{K} a-3 \mathrm{a}(\mathrm{I}-\mathrm{N})$ & pyrargyrite & 61.20 & - & - & - & 15.91 & 5.08 & 17.65 & 99.84 \\
\hline $\mathrm{Ka}-3 \mathrm{~b}(\mathrm{I}-\mathrm{N})$ & pyrargyrite & 62.20 & - & - & - & 21.23 & 0.64 & 16.481 & 100.55 \\
\hline $\mathrm{Ka}-3 \mathrm{~b}(\mathrm{I}-\mathrm{N})$ & pyrargyrite & 60.08 & 0.04 & - & - & 21.27 & 0.42 & 17.45 & 99.26 \\
\hline $\mathrm{K} 1-1(\mathrm{I}-\mathrm{C})$ & pearceite & 68.70 & 8.04 & - & - & 4.02 & 4.82 & 15.321 & 100.90 \\
\hline K4-18 (TV-S) & polybasite* & 71.83 & 439 & - & - & 2.82 & 4.49 & 14.70 & 98.23 \\
\hline K4-16 (IV-S) & polybasite & 69.44 & 6.33 & - & - & 7.08 & 2.56 & 14.611 & 100.02 \\
\hline
\end{tabular}

$\mathrm{N}$ : northern part, C: central part, S: southern part of orebody; -: not detected; polybasite $^{*}=$ arsenpolybasite. or as irregular anhedral grains in interstices of coarsegrained or later fine-grained galena. The blebs in the coarse-grained galena are commonly less than $20 \mu \mathrm{m}$ across. The grains of the pyrargyrite-proustite series associated with the fine-grained galena are coarser, and can be tens to more than $100 \mu \mathrm{m}$ in diameter. The mineral occurring in the southern part of a major orebody commonly contains higher arsenic (11 wt.\%) and trace amount of copper $(0.52 \mathrm{wt} . \%)$, and belongs to an intermediate member of the pyrargyrite-proustite series. The content of arsenic varies greatly, even in the same ore sample. The mineral occurring in the northern part or associated with later fine-grained galena is the nearly pure Sb-end member (Table 1).

\section{Geochemical Behavior of Silver and Evolution of Silver Minerals}

The occurrence of minor silver in galena has been extensively documented (e.g., Fleischer 1955, Craig 1967, Hall \& Heyl 1968, Karup-Møller 1971, Scott 1976, Pattrick 1984, Foord et al. 1988, Foord \& Shawe 1989, Jeppsson 1987, Cabri 1992, Sharp \& Buseck 1993). Silver is either present in solid solution, involved in an isomorphous substitution for $\mathrm{Pb}$, or as very finegrained discrete minerals.

The substitution model is believed to involve $2 \mathrm{~Pb}^{2+}$ $=\mathrm{Ag}^{+}+\mathrm{Bi}^{3+}\left( \pm \mathrm{Sb}^{3+}\right)$, and it causes a decrease in the unit-cell dimension of galena (e.g., Karup-Møller 1971, Foord et al. 1988, Foord \& Shawe 1989). The amount of silver able to substitute for lead without $\mathrm{Bi}^{3+}$ in galena does not seem to be significant. As mentioned above, there is no distinct variation in the unit-cell dimension of galena in the Kangjiawan deposit, and silver, antimony and bismuth are less than $0.01 \mathrm{wt} . \%$ by EPMA in most of grains of galena analyzed. The results of experiments in the system $\mathrm{Ag}_{2} \mathrm{~S}-\mathrm{PbS}$ show that the maximum solubility of $\mathrm{Ag}_{2} \mathrm{~S}$ in $\mathrm{PbS}$ is about 0.4 mole $\%$ at $615^{\circ} \mathrm{C}$ (Hook 1960). The solubility of $\mathrm{AgSbS}_{2}$ in $\mathrm{PbS}$ was found to be less than 4 mole $\%$ at $300^{\circ} \mathrm{C}$, less than 2 mole $\%$ at $200^{\circ} \mathrm{C}$, and only minor amounts of $\mathrm{Ag}$ and $\mathrm{Sb}$ in galena can be formed at room temperature (Hoda \& Chang 1975, Amcoff 1976). Although the extent of solid solution of galena toward polybasite and pyrargyrite has not been studied comprehensively, it seems reasonable to expect that it will be very limited in nature. As a result of a decrease in temperature, most of the structurally bound silver in galena will be expelled to the nearest weakly bonded planes (cleavages) or grain boundary, as observed in the Kangjiawan deposit and other deposits (e.g., Ramdohr 1980, Sandecki \& Amcoff 1981).

Many researchers (e.g., Hall \& Czamanske 1972, Amcoff 1976, Wu \& Petersen 1977, Jeppsson 1987, Cabri 1992) have recognized that the silver contents in Ag-bearing ores may be partly or principally accounted for by Ag-bearing minerals, especially argentian tetrahedrite. However, argentian tetrahedrite is rare in the 
Kangjiawan deposit, particularly in the northern part. Amcoff (1976) suggested: "If $\mathrm{Cu}, \mathrm{Zn}$ and other metals also are present at the time of crystallization, the $\mathrm{Sb}$ and Ag will be incorporated into minerals such as tetrahedrite." Johnson \& Jeanloz (1983) proved that the most stable structure of tetrahedrite has an approximate composition of $\mathrm{Cu}_{10}(\mathrm{Fe}, \mathrm{Zn})_{2}(\mathrm{Sb}, \mathrm{As})_{4} \mathrm{~S}_{13}$, and Pattrick \& Hall (1983) also pointed out that the substitution of Ag for $\mathrm{Cu}$ in tetrahedrite is controlled by $\mathrm{Fe}$ substitution. The presence of a small amount of argentian tetrahedrite in the Kangjiawan deposit may result from a low level of copper and iron in the mineralizing fluids, and from the fact that coupled substitution of $\mathrm{Ag}+\mathrm{Fe}$ for 2 $\mathrm{Cu}$ could not occur during crystallization.

The XRF results show that most of $\mathrm{Pb}-\mathrm{Zn}$ ores in the deposit are characterized by $\mathrm{Ag}>\mathrm{Cu}>\mathrm{Sb}$ content. From south to north, a decreasing amount of copper and an increasing amount of silver are found in the major orebodies. Corresponding to the changes in copper and silver concentrations, the assemblages of silver minerals change from the tetrahedrite + freibergite + pearceite + arsenpolybasite + pyrargyrite-proustite in the southern part to polybasite-arsenpolybasite + pyrargyrite in the central part, and to pyrargyrite in the northern part. The change in the assemblages of silver minerals in the Kangjiawan deposit may result mainly from the evolution in the chemical environment of the hydrothermal fluid.
A simplified evolution of silver minerals occurring in the Kangjiawan deposit is summarized in Figure 6. The diagram shows that in Ag-bearing $\mathrm{Pb}-\mathrm{Zn}$ ores, silver first enters tetrahedrite, then forms Ag-sulfosalts or sulfides. Where the $\mathrm{Cu}$ content of ores is high, tetrahedrite will be the major Ag-bearing mineral; if the $\mathrm{Cu}$ content is very low, it will yield a complex Ag-Sb(As)$\mathrm{S}$ mineral assemblage, as the arrow in Figure 6 indicates, or an acanthite - native silver assemblage.

\section{Conditions of Mineralization: Fluid-InCLusion Evidence}

On the basis of our study, four stages of mineralization can be recognized in the Kangjiawan deposit: (1) pyrite stage, (2) $\mathrm{Pb}-\mathrm{Zn}$-Ag stage, (3) $\mathrm{Pb}-\mathrm{Ag}$ stage, and (4) late Sp (sphalerite) stage (Fig. 7). Ores in the deposit mainly formed in the pyrite and $\mathrm{Pb}-\mathrm{Zn}-\mathrm{Ag}$ stages. The mineralization that led to the $\mathrm{Pb}-\mathrm{Ag}$ and late sphalerite stages was recognized locally, on a small scale only.

To constrain the conditions of mineralization in the deposits, fluid inclusions in quartz were studied for pyrite- $\mathrm{Pb}-\mathrm{Zn}$ ores from two locations, the northern part of orebody I (117 line) and the northern part of orebody IV (127 line, Fig. 2B). Quartz samples from orebody I are white euhedral crystals 0.3 to $1 \mathrm{~cm}$ across, and those

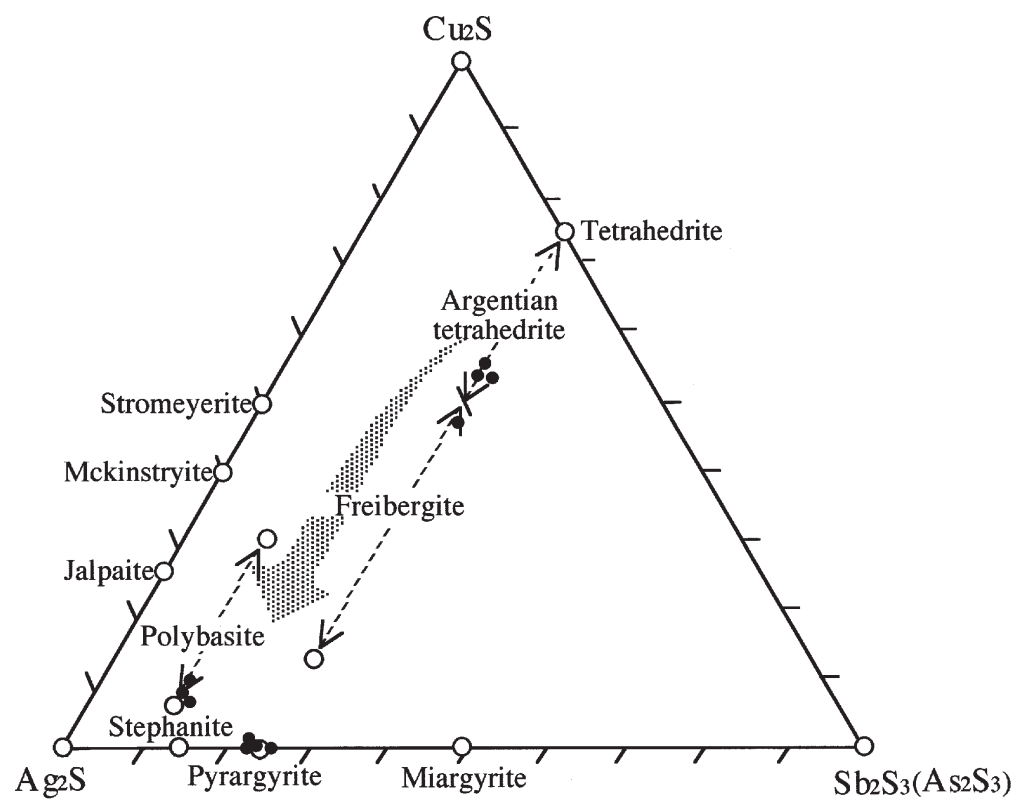

FIG. 6. Triangular diagram of $\mathrm{Ag}-\mathrm{Cu}$ sulfosalts. Black dots show representative compositions of some silver minerals in the Kangjiawan deposit. The arrow indicates the trend of evolution of silver mineral assemblages during mineralization. The compositional ranges of silver minerals are shown by dashed lines for reference. 


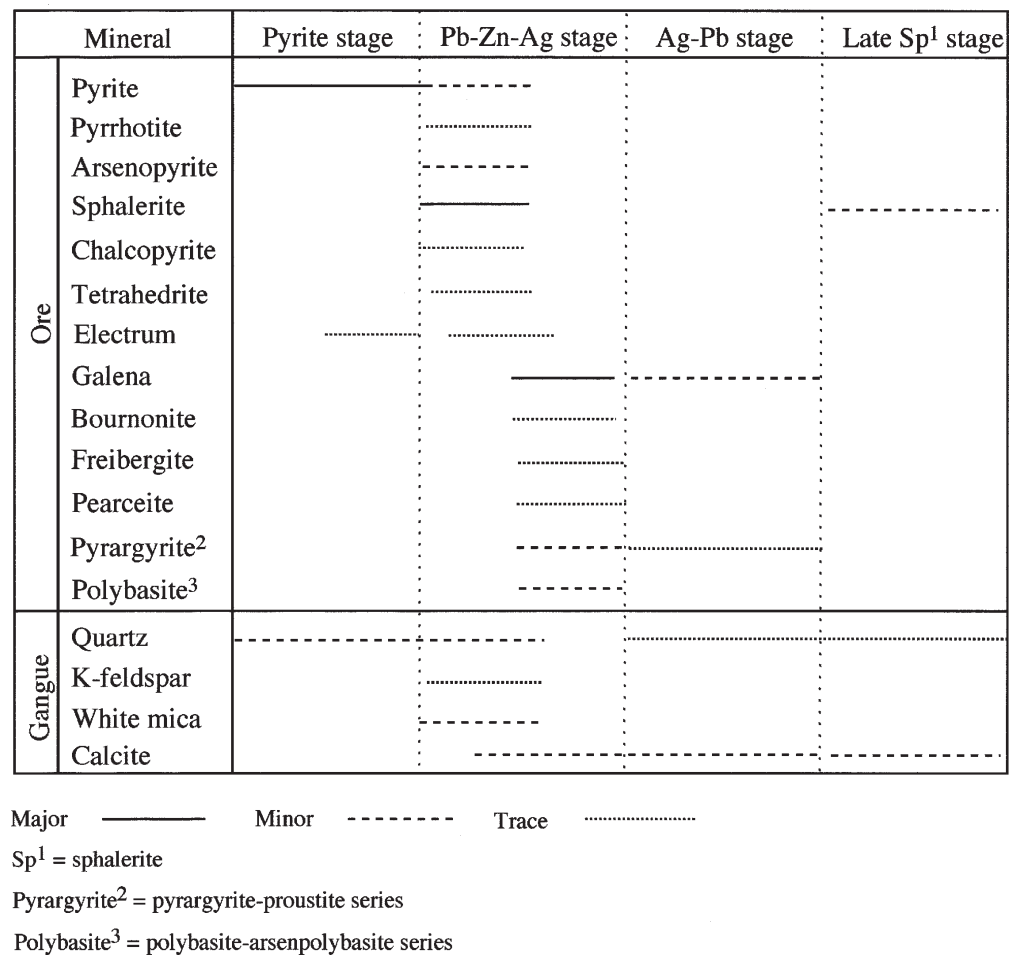

FIG. 7. Paragenetic sequence of ore minerals, Kangjiawan deposit.

from orebody IV are white and massive. Quartz is intergrown with pyrite, and fractures in the quartz are filled by sphalerite and galena, suggesting that the quartz formed in the pyrite stage.

Quartz contains a small numbers of primary inclusions (type P), and abundant secondary inclusions (type $\mathrm{S}$ ) in healed microfractures. Both types are simple twophase liquid-vapor inclusions, with no visible immiscible $\mathrm{CO}_{2}$. Type-P inclusions are large in diameter (20 to $50 \mu \mathrm{m}$ across) and have 15 to $20 \%$ vapor. Type-S inclusions are small in size (less than $20 \mu \mathrm{m}$ ), and have 5 to $10 \%$ vapor.

Type-P inclusions are characterized by low ice-melting temperatures $(\mathrm{Tm})$, indicating a high salinity. The values of $\mathrm{Tm}$ are -18.8 to $-19.5^{\circ} \mathrm{C}$, and homogenization temperatures (Th) range from 307 to $312^{\circ} \mathrm{C}$, with a mean of $310^{\circ} \mathrm{C}$, for orebody I. Only one primary inclusion was studied in quartz from orebody IV, and Tm and $\mathrm{Th}$ are $-19^{\circ} \mathrm{C}$ and $303^{\circ} \mathrm{C}$, respectively.

On the basis of the range of Tm and Th values, secondary inclusions can be divided into three subtypes, S-a, S-b and S-c (Fig. 7). Type S-a inclusions have a moderate salinity, with Tm ranging from -8.8 to $-11.5^{\circ} \mathrm{C}$ for orebody $\mathrm{I}$, and -9 to $-10^{\circ} \mathrm{C}$ for orebody IV . Homogenization temperatures for type $\mathrm{S}-\mathrm{a}$ inclusions from orebody I range generally from 300 to $325^{\circ} \mathrm{C}$, with a mean of $316^{\circ} \mathrm{C}$, although some lower $\left(276^{\circ} \mathrm{C}\right)$ and higher $\left(375^{\circ} \mathrm{C}\right)$ values exist. Homogenization temperatures range from 270 to $318^{\circ} \mathrm{C}$, with a mean of $305^{\circ} \mathrm{C}$, for orebody IV.

Type S-b inclusions occur in samples from orebody I, and are characterized by a low salinity. The narrow range of $\mathrm{Tm}$, from -2 to $3^{\circ} \mathrm{C}$, and a wide range of $\mathrm{Th}$, from 241 to $330^{\circ} \mathrm{C}$, may be the result of necking down. The low-temperature-type $\mathrm{S}-\mathrm{c}$ inclusions were found in quartz from orebody IV. Homogenization temperatures range from 122 to $130^{\circ} \mathrm{C}$, with a mean of $127^{\circ} \mathrm{C}$, and Tm from -3 to $-5.6^{\circ} \mathrm{C}$.

Primary inclusions (type P) in quartz from orebody I and IV formed in the pyrite stage, and inclusions of type $\mathrm{S}-\mathrm{a}$ probably formed in $\mathrm{Pb}-\mathrm{Zn}-\mathrm{Ag}$ stage. The values of Th for primary inclusions (type P) and secondary inclusions (type S-a) show a slight decrease from south (orebody I) to north (orebody IV), suggesting that the mineralizing fluids flowed from south to north, as reported by Yang (1985). Yang (1985) investigated the distribution of temperature in the Kangjiawan deposit systematically using the decrepitation method (Fig. 2B). Although quantitative values of temperatures may not be valid, the tendency of a northward decrease in temperature can be recognized. We believe that the mineralizing fluids in the Kangjiawan deposit and in the 


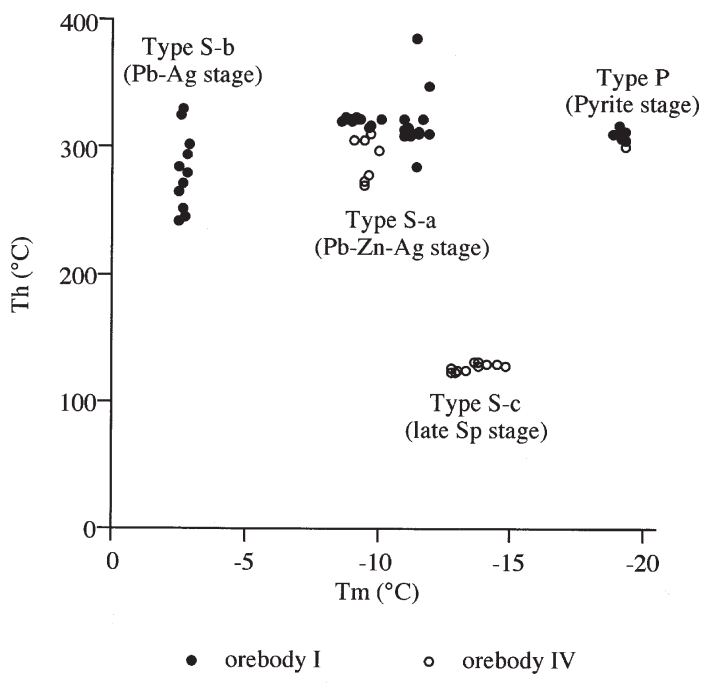

FIG. 8. Homogenization temperature (Th) versus ice melting temperature $(\mathrm{Tm})$ diagram showing probable environments of four stages of mineralization.

Shuikoushan skarn deposit came from the same mineralization system. Secondary inclusions of type $\mathrm{S}-\mathrm{b}$ and type $\mathrm{S}-\mathrm{c}$ possibly formed in the $\mathrm{Pb}-\mathrm{Ag}$ stage and late sphalerite stage, respectively (Fig. 8).

To compare with the homogenization temperatures of fluid inclusions, the temperature of mineralization has been estimated using the arsenopyrite geothermometer (Scott 1983, Sharp et al. 1985). Arsenopyrite in the Pb$\mathrm{Zn}-\mathrm{Ag}$ stage from orebody I, III and IV has been analyzed using EPMA (Table 2). The arsenopyrite shows a small compositional variation $(<2$ at. \%) in As content, but does not express any clear compositional zonation within a grain. Since the arsenopyrite coexists with pyrite and the activity of $S_{2}$ does not affect its composition (Sharp et al. 1985), the results indicate an average temperature of about $310^{\circ} \mathrm{C}$ for orebody $\mathrm{I}, 260^{\circ} \mathrm{C}$ for orebody III, and $280^{\circ} \mathrm{C}$ for orebody IV. The temperatures coincide with homogenization temperatures obtained from fluid inclusions. The result indicates that the pressure correction for the homogenization temperatures may well be minimal. As no evidence of boiling has been observed in the fluid inclusions, the depth of mineralization is inferred to have been 2 to $3 \mathrm{~km}$.

The inferred change in salinity of the fluid inclusions is probably due to mixing of the hydrothermal fluid with meteoric groundwater. Because of the presence of abundant carbonates and minor white mica and K-feldspar, the mineralizing environment must have been near-neutral to weakly alkaline in $\mathrm{pH}$ (e.g., Inoue 1995, Reed 1997).
TABLE 2. RESULTS OF EPMA ANALYSES OF ARSENOPYRITE FROM THE KANGJAWAN DEPOSIT, CHINA

\begin{tabular}{|c|c|c|c|c|c|c|}
\hline \multirow[t]{2}{*}{ Orebody } & \multirow[t]{2}{*}{ \# } & \multicolumn{4}{|c|}{ composition in wt. $\%$} & \multirow{2}{*}{$\begin{array}{c}\text { in at. } \% \\
\text { As }\end{array}$} \\
\hline & & $\mathrm{Fe}$ & $\mathrm{S}$ & As & total & \\
\hline I & 5 & 35.63 & 22.19 & 42.23 & 100.05 & 29.80 \\
\hline III & 7 & 35.58 & 22.68 & 41.17 & 99.42 & 29.00 \\
\hline IV & 6 & 35.65 & 22.45 & 41.87 & 99.97 & 29.40 \\
\hline
\end{tabular}

\#: number of grains analyzed.

\section{ACKNOWLEDGEMENTS}

The authors thank the Geology Department of the Kangjiawan mine of CNNC for help during the study. We gratefully acknowledge L. L. Y. Chang, B. Mishra, R.F. Martin, and another reviewer, for detailed comments on the paper.

\section{REFERENCES}

AmCOFF, Ö. (1976): The solubility of silver and antimony in galena. Neues Jahrb. Mineral., Monatsh., 247-261.

CABRI, L. (1992): The distribution of trace precious metals in minerals and mineral products. Mineral. Mag. 56, 289-308.

Craig, J.R. (1967): Phase relations and mineral assemblages in the Ag-Bi-Pb-S system. Mineral. Deposita 1, 278-306.

EBEL, D.S. \& SACK, R.O. (1991): Arsenic-silver incompatibility in fahlore. Mineral. Mag. 55, 521- 528.

FLEISCHER, M. (1955): Minor elements in some sulfide minerals. Econ. Geol., Fiftieth Anniv. Vol. 2, 970-1024.

Foord, E.E. \& SHAwE, D.R. (1989): The Pb-Bi-Ag-Cu-(Hg) chemistry of galena and some associated sulfosalts: a review and some new data from Colorado, California and Pennsylvania. Can. Mineral. 27, 363-382.

\& Conklin, N.M. (1988): Coexisting galena, $\mathrm{PbS}_{\mathrm{ss}}$ and sulfosalts: evidence for multiple episode of mineralization in the Round Mountain and Manhattan gold districts, Nevada. Can. Mineral. 26, 355-376.

Hall, W.E. \& CZAmansKe, G.K. (1972): Mineralogy and trace element content of the Wood River lead-zinc deposits, Blaine County, Idaho. Econ. Geol. 67, 350-361.

\& HeYL, A.V. (1968): Distribution of minor elements in ore and host rock, Illinois-Kentucky fluorite district and upper Mississippi Valley zinc-lead district. Econ. Geol. 63, 655-670.

HodA, S.N. \& ChAnG, L.L.Y. (1975): Phase relations in the systems $\mathrm{PbS}-\mathrm{Ag}_{2} \mathrm{~S}-\mathrm{Sb}_{2} \mathrm{~S}_{3}$ and $\mathrm{PbS}-\mathrm{Ag}_{2} \mathrm{~S}-\mathrm{Bi}_{2} \mathrm{~S}_{3}$. Am. Mineral. 60, 621-633. 
Hook, H.J.V. (1960): The ternary system $\mathrm{Ag}_{2} \mathrm{~S}-\mathrm{Bi}_{2} \mathrm{~S}_{3}-\mathrm{PbS}$. Econ. Geol. 55, 759-788.

INOUE, A. (1995): Formation of clay minerals in hydrothermal environments. In Origin and Mineralogy of Clay (B. Velde, ed.). Springer-Verlag, Berlin, Germany (268-303).

JEPPSSON, M. (1987): Mineral chemistry of silver in antimony and bismuth rich sulfide ores in Bergslagen, central Sweden. Neues Jahrb. Mineral., Monatsh., 205-216.

JOHNSON, M.L. \& JEANLOZ, R. (1983): A Brillouin-zone model for compositional variation in tetrahedrite. Am. Mineral. 68, 220-226.

KARUP-MøLLER, S. (1971): On some exsolved minerals in galena. Can. Mineral. 10, 871-876.

LI, ZHENG-QIN (1991): Silver distributions and mineralogy in several large silver deposits, Hunan Province. Acta Mineral. Sinica 11, 148-154 (in Chinese).

LI, ZHI \& LIU, ZHI-YUAN (1984): The study on the existing forms of silver and cadmium in lead-zinc ore from the Kangjiawan deposit of the Shuikoushan mineralized district. Nonferrous Metals Geology of Hunan Provice, 37-48 (in Chinese).

Lin, Mu-Shong \& YAng, HuAn-Jie (1986): Existing forms and enriching regularities of gold in the Kangjiawan lead-zincgold mineralized area of Shuikoushan mineralized district. Nonferrous Metals Geology of Hunan Provice, 58-75 (in Chinese).

LiU, QING-SHUANG (1986): The meaning of structure-collapse and karst during mineralization process of the Kangjiawan lead-zinc deposit. Geol. Prosp. 22, 1-9 (in Chinese).

(1996): A discussion on the mineralizing conditions and genesis of the Kangjiawan lead-zinc deposit. Geol. Explor. Non Metal. 5, 340-346 (in Chinese).

LIU, ZHEN-GuO (1990): A discussion on gold and silver enriching characteristics in the Kangjiawan $\mathrm{Pb}-\mathrm{Zn}-\mathrm{Au}$ deposit. Nonferrous Metals Geology of Hunan Provice, 18-21 (in Chinese).

PATtRick, R.A.D. (1984): Sulphide mineralogy of the Tomnadashan and the Corrie Buie lead veins, south Loch Tayside, Scotland. Mineral. Mag. 48, 85-91.

\& HaLl, A.J. (1983): Silver substitution in synthetic zinc, cadmium, and iron tetrahedrites. Mineral. Mag. 47, 441-451.

RAMDOHR, P. (1980): The Ore Minerals and Their Intergrowths. Akademie-Verlag, Berlin, Germany.

REED, M.H. (1997): Hydrothermal alteration and its relationship to ore fluid composition. In Geochemistry of Hydrothermal Ore Deposits (H. L. Barnes ed.). John Wiley \& Sons, Inc., New York, N.Y. (303-366).
RILEY, J.F. (1974): The tetrahedrite-freibergite series, with reference to the Mount Isa $\mathrm{Pb}-\mathrm{Zn}-\mathrm{Ag}$ orebody. Mineral. Deposita 9, 117-124.

SACK, R.O. (1992): Thermochemistry of tetrahedrite-tennantite fahlores. In The Stability of Minerals (G.D. Price \& N.L. Ross, eds.). Champan \& Hall, London, U.K. (243-266).

SANDECKI, J. \& AMCOFF, Ö. (1981): On the occurrence of silver-rich tetrahedrite at Grapenberg Norra, central Sweden. Neues Jahrb. Mineral., Abh. 141, 247-261.

SCOTT, J.D. (1976): A microprobe-homogeneous intergrowth of galena and matildite from the Nipissing mine, Cobalt, Ontario. Can. Mineral. 14, 182-184.

ScotT, S.D. (1983): Chemical behaviour of sphalerite and arsenopyrite in hydrothermal and metamorphic environments. Mineral. Mag. 47, 427-435.

Sharp, T.G. \& Buseck, P.R. (1993): The distribution of Ag and $\mathrm{Sb}$ in galena: inclusions versus solid solution. Am. Mineral. 78, 85-95.

Sharp, Z.D., Essene, E.J. \& Kelly W.C. (1985): A re-examination of the arsenopyrite geothemometer: pressure considerations and applications to natural assemblages. Can. Mineral. 23, 517-534.

Song, Shu-He (1989): Deposits of China. Geologic Publication House, Beijing, People's Republic of China (in Chinese).

Wu, I. \& Petersen, U. (1977): Geochemistry of tetrahedrite and mineral zoning at Casapalca, Peru. Econ. Geol. 72, 993-1016.

YANG, ChuAn-Yi (1985): The finding and genesis of the Kangjiawan lead-zinc deposit. Geol. Pros. 21, 1-7 (in Chinese).

YANG, HuAN-JiE \& Lin, RU-SHONG (1987): Existing forms and enriching regularities of arsenic in the Kangjiawan mineralized area. Nonferrous Metals Geology of Hunan Provice, 32-36 (in Chinese).

ŻENG, NAN-SHI (1989): Analyses on physico-chemical forming conditions of tetrahedrite-freibergite from a tungsten ore deposit, Hunan Province. Mineral. Petrol. 9, 87-93 (in Chinese).

Zhang, Shuen-Ying (1990): The occurrences of silver in the ores and its significance for exploration in the Kangjiawan deposit. Geol. Resources 4, 44-49 (in Chinese).

Received March 15, 1999, revised manuscript accepted January 10, 2000. 